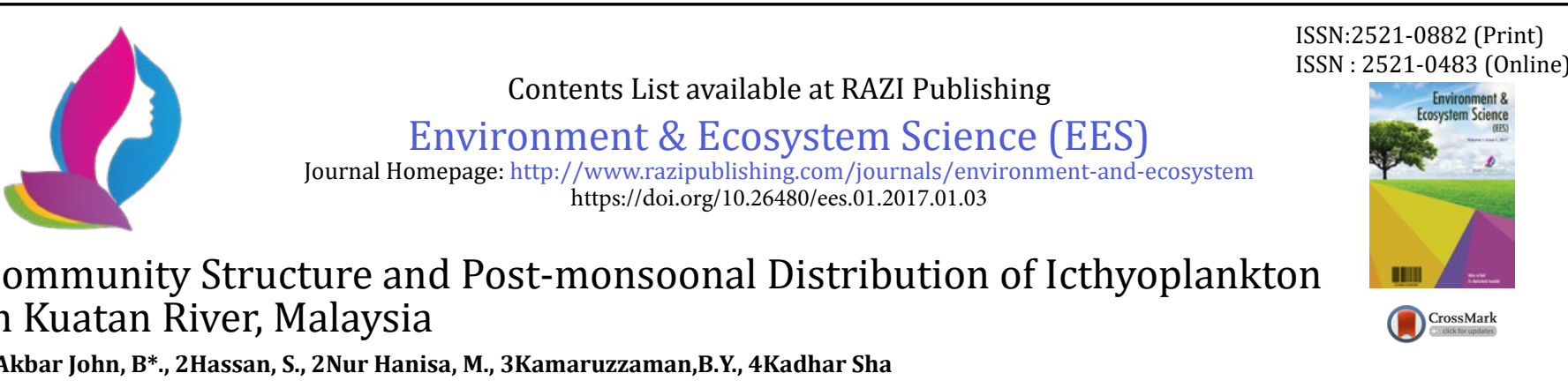

\title{
Community Structure and Post-monsoonal Distribution of Icthyoplankton in Kuatan River, Malaysia
}

1Akbar John, B*., 2Hassan, S., 2Nur Hanisa, M., 3Kamaruzzaman,B.Y., 4Kadhar Sha

1INOCEM Research Station (IRS), 2Department of Biotechnology, 3Department of Marine Science, Kulliyyah of Science, International Islamic University Malaysia (IIUM), Kuantan, Pahang, Malaysia. 4Centre of Advanced Study in Marine Biology (CASMB), Annamalai University, India

*Corresponding author akbarjohn50@gmail.com

This is an open access article distributed under the Creative Commons Attribution License, which permits unrestricted use, distribution, and reproduction in any medium, provided the original work is properly cited.

\begin{tabular}{|c|c|}
\hline ARTICLE DETAILS & ABSTRACT \\
\hline Article history: & $\begin{array}{l}\text { Present study was aimed to investigate the community structure and size distribution of Icthyoplankton sampled } \\
\text { from Kuantan River, Malaysia. Sampling was conducted from May } 2015 \text { to August } 2015 \text { using modified bubu }\end{array}$ \\
\hline Received 27 September 2016 & light trap in Kuantan river and its immediate tributary (Belat river). A total of 78 larvae representing 4 families \\
\hline $\begin{array}{l}\text { Accepted } 13 \text { December } 2016 \\
\text { Available online } 10 \text { January } 2017\end{array}$ & and 6 genus were sampled and size distribution were measured using Dino capture $2.0 \mathrm{v}$ portable microscope. \\
\hline 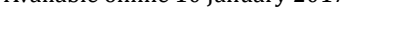 & Significant influences of selected water quality parameters on the distribution of Icthyoplankton were observed \\
\hline Keywords: & $(\mathrm{p}<0.05)$. Representatives of larvae belong to gobiidae, eleotridae ambassidae and leiognathidae were recorded \\
\hline & during sampling and few larvae were unable to be distinguished morphologically and hence stored for further DNA \\
\hline $\begin{array}{l}\text { Icthyoplankton, Community succession, } \\
\text { fish larvae post monsoon effect }\end{array}$ & barcoding. Modified bubu light trap method designed and adopted in this study can be successfully used to sample \\
\hline & Icthyoplankton in rivers where the depth and turbidity are the key limiting factors during sampling. \\
\hline
\end{tabular}

\section{INTRODUCTION}

Icthyoplankton are more sensitive life history stages exposed to number of environmental stresses in the aquatic water body [1]. Their assemblages are directly related to the spawning

strategies of brooders and driven by ocean currents and water mass $[2,3]$. The role of estuaries in larval ontogenesis are well documented in literatures as these water bodies provide an excellent nursery ground and hiding place for juvenile fishes and larvae [4] besides offering abundant food supply in macrophyte beds [5] and Higher spring/summer water temperature compared to the open ocean [6]. In fact, the Icthyoplankton distribution and in estuaries are more complex in terms of composition and abundance due to an interactive effects of various physical, chemical [7] and biological factors [8] and hence they are sensitive to ambient water quality parameters.

Recently, East Peninsular Malaysia has faced severe flood cases during northeast monsoonal cycle between mid-December 2014 and January 2015) with at least $>60 \%$ above the normal precipitation rate that eventually led to the loss of $\$ 560$ million. Among these, Kuantan River is facing serious pressure as people continue to utilize coastal zone for various recreational and industrial activities. At present, more than 300 families involved in fishing in Kuantan River using 150 small boats. Apparently, very few studies were concentrated on fish biodiversity in Kuantan river [9]. It is presumed that due to heavy rain fall during the recent flood in Malaysia, considerable amount of organic pollutants might have reached Kuantan river through land run off which might have alter the sensitive faunal distribution and diversity. Hence, the present study was aimed to investigate community composition and post-monsoonal succession of Icthyoplankton in Kuantan river.

\subsection{EXPERIMENTAL DESIGN}

Icthyoplankton sampling was carried out in two sampling stations namely kuantan river [LKIM] and its immediate tributary (Belat River) during ebb tidal cycle (Fig 1). Water quality parameters such as Temperature, Salinity, $\mathrm{pH}$, Dissolved oxygen, conductivity and turbidity were recorded using hydrolab 4.0. Due to technical constrains such as high turbidity, uneven water depth in Kuantan river (varied from $4 \mathrm{~m}$ to $13 \mathrm{~m}$ ) besides inefficiency of plankton sampling net (mesh size $500 \mu$ ), a modified bubu light trap (Figure 2) was used during sampling between May and August 2015.

Modified Bubu light trap used in this study is $5 \times 4 \times 3$ feet $(\mathrm{LxWxH})$ size having conical shaped opening in one side towards the interior section of the trap (Fig 2). The skeleton is made up of bamboo or cylindrical wood which in turn covered completely by $2 \mathrm{~mm}$ thickness stainless steel wire meshes with the mesh diameter of $2.5 \mathrm{~cm} 2$. An underwater light was placed in transparent plastic container and the lid was sealed with commercially available silicone gel and parafilm to ensure maximum light emission. An anchor was tied at the bottom of the cage to make sure the cage does not wash away during water current. The complete set up (modified bubu light trap) was cover by plastic window mesh sheet (mesh size <1mm) (Fig 3). The net was deployed under water at the depth of 4 meter in both sampling stations for 16 hours overnight.

Icthyoplankton samples were measured under Dino Capture 2.0 portable microscope and stored in $70 \%$ ethanol for further downstream application. Samples were identified morphologically to the lowest possible taxon using standard references [10-16] Taxonomic classification was according to Nelson [17]. Size classes of larvae were tabulated with observed physicochemical parameters of the ambient water for Pearson's correlation matrix analysis. Size class variation of Icthyoplankton was represented in Mean \pm SD. Paired sample $t$ test was used to compare the efficiency of light trap method over plankton net sampling.

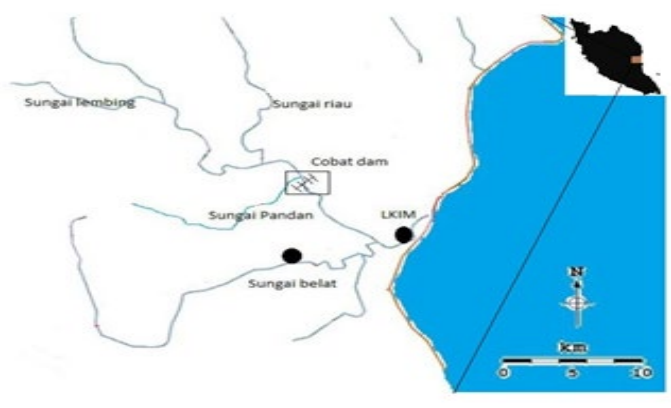

Fig 1: Location of the sampling sites at Kuantan River. LKIM: Active fishing activities and boat transportation can be noted in this area. Sungai belat: immediate tributary of Kuantan River close to river mouth. 


\section{Modified bubu light trap}

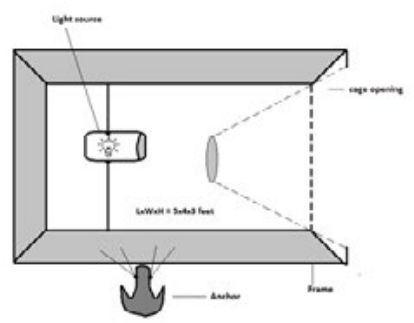

Fig. 2: The schematic representation of modified bubu light trap used in sampling

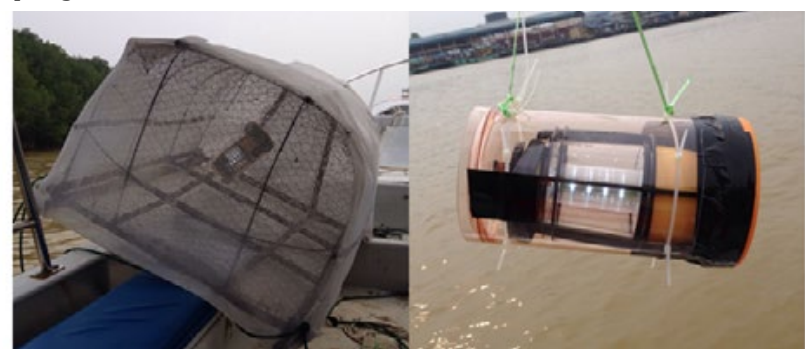

Fig. 3: Modified bubu light trap and the prepared internal light source used to attract the Icthyoplankton during sampling

\subsection{RESULTS AND DISCUSSION}

In this present sampling 78 Fish larval samples were collected belong to 4 families, 6 genus in 2 sampling stations in Kuantan river. An efficiency of modified bubu light trap method $(\mathrm{n}=78)$ over horizontal plankton net $(\mathrm{n}=2)$ sampling showed significant difference in total catch $(\mathrm{P}<0.001)$. Significant difference in icthyoplankton distribution and diversity was noted between sampling stations $(\mathrm{P}<0.05)$. Mean standard length of larvae captured under the light trap was $13 \pm 4.3 \mathrm{~mm}$ which is almost 12 times larger than those caught using plankton net. However, all samples in the light trap was alive and without any loss of appendages while the samples collected from plankton net had many physical damages (Table 1). Previous studies have shown the efficiency of different light trap methods in sampling sensitive Icthyoplankton in its full form (without loss of appendages) compared to bongo or other plankton net sampling [18]. Even though, this method has its own limitation as it cannot attract fishes which are photo sensitive, the method is widely used for sampling fish larvae for various downstream applications such as identifying morphologically cryptic samples using DNA barcoding techniques [1920] or the stress undergone by the sensitive larval forms in its ambient environment by analyzing its gene expression [21]. In this research, the light trap method has been slightly modified to collect fish larvae from the sampling zones where water depth and turbidity are the major limiting factors. Bottom topology of Kuantan river showed sudden depth variation (from 4 to13meters) and high turbidity due to constant movement of fish vessels and hence sampling fish larvae using Bongo net is technically challenging and hence light trap method was adopted in this study.

Significant variation in dissolved oxygen (DO), salinity (ppt), specific conductivity $(\mathrm{ms} / \mathrm{cm})$ and turbidity (NTU) were observed between sampling stations $(\mathrm{P}<0.05)$. While there was no considerable variation in water temperature and $\mathrm{pH}$ between sampling stations (Table 2). Higher turbidity in kuantan river (LKIM port) compared to Belat river might be due to constant transportation of fishing vessels in this area. Similarly higher $\mathrm{pH}$ value compared to the previous report in kuantan river [9] might be due to less rainfall during non-monsoonal period (March-July). Pearson correlation analysis showed significant effect of salinity, DO, turbidity on the larval distribution in both sampling stations $(\mathrm{P}<0.05)$ while other parameters such as water temperature and $\mathrm{pH}$ had no significant effect on larvae distribution. Size class distribution of larvae sampled using both plankton net (mesh size $500 \mu$ ) and modified bubu light trap showed most of the larvae were of $10-20 \mathrm{~mm}$ length (69\%) followed by $>30 \mathrm{~mm}(19 \%)$, 20-30mm (7\%) and 0-10mm ( 4\%) (Fig 4).

Unlike the previous study by Jalal et al., (2012) who observed the distribution of fishes belong to 12 families having major representation by Ariidae (up to $50 \%$ ), Lutjanidae and Lactaridae families in kuantan river, present study have shown the dominance of Gobiidae fishes which might probably due to the drifting of gobiid larvae from river mouth during the ebb tidal cycle. Other fish larvae sampled were showing a benthic characteristic that might be due to the low depth in Kuantan River besides the position of light trap during sampling. Kuantan River has been washed away due to heavy land and river run off which eventually reflected in less number of larval sampling in this study.

Table 1: Icthyoplankton samples collected from two sampling stations. Samples were identified to the lowest possible taxon. Pictures of unidentified samples were also depicted.
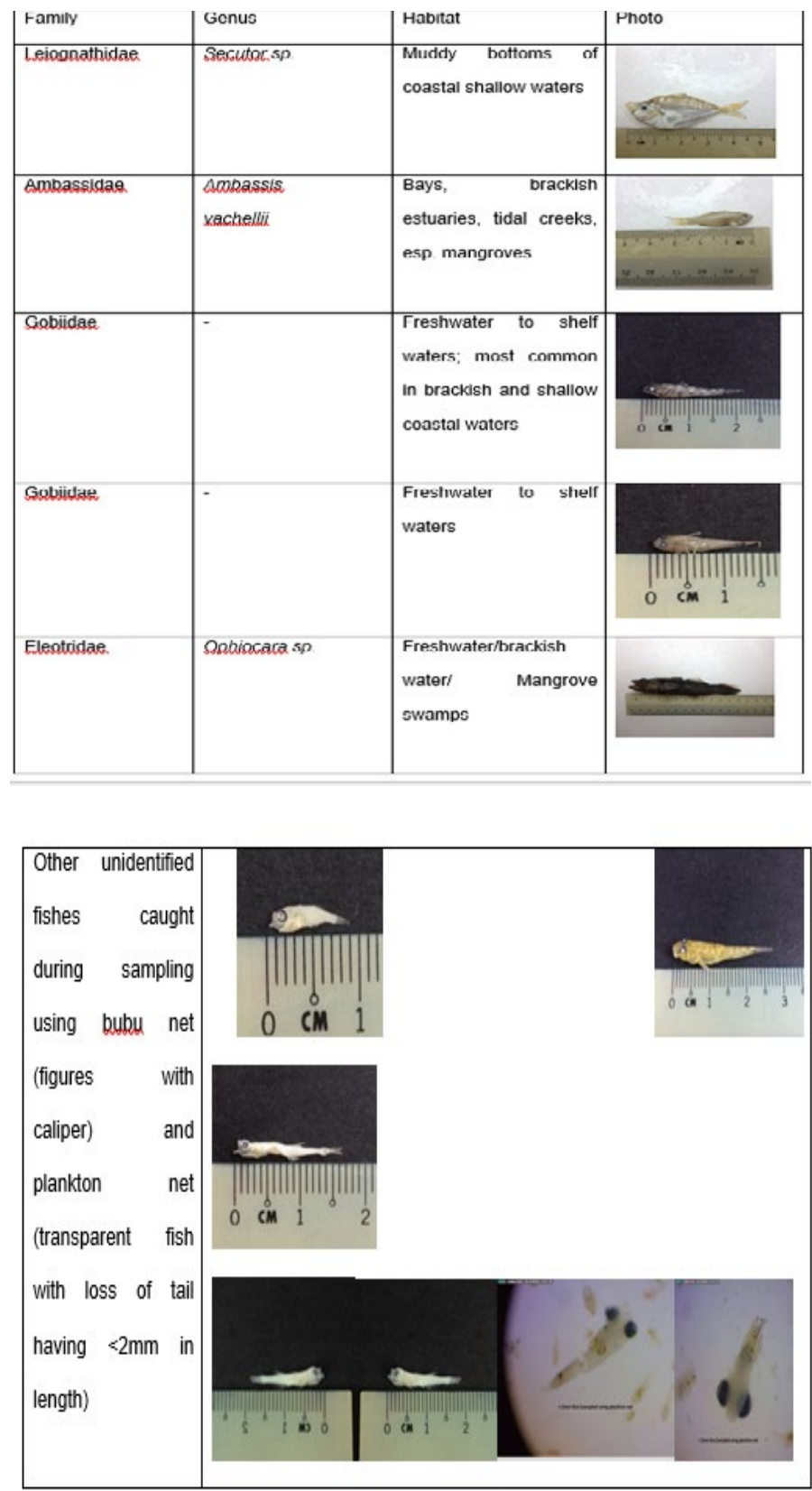

Table 2: Physicochemical parameters recorded in sampling stations (Data expressed in Mean $+\mathrm{SD}$ ). Different alphabets between sampling zones showed significant variation between sampling sites.

\begin{tabular}{|l|l|l|}
\hline Parameters & Kuantan river & Belat river \\
\hline Temperature $\left({ }^{\circ} \mathrm{C}\right)$ & $29.56 \pm 1.43^{\mathrm{a}}$ & $29.6 \pm 0.87^{\mathrm{a}}$ \\
\hline Dissolved Oxygen & $5.01 \pm 0.33^{\mathrm{a}}$ & $2.77 \pm 0.41^{\mathrm{b}}$ \\
\hline $\mathrm{pH}$ & $7.10 \pm 0.2^{\mathrm{a}}$ & $5.56 \pm 0.31^{\mathrm{a}}$ \\
\hline Salinity (pot) & $12.23 \pm 2.3^{\mathrm{a}}$ & $6.58 \pm 0.41^{\mathrm{a}}$ \\
\hline Specific Conductivity (ms/cm) & $3.97 \pm 0.67^{\mathrm{a}}$ & $12.80 \pm 1.02^{\mathrm{b}}$ \\
\hline Turbidity (NTU) & $40.7 \pm 2.59^{\mathrm{a}}$ & $3.40 \pm 1.34^{\mathrm{b}}$ \\
\hline
\end{tabular}

Fig. 3: Size class variation of Icthyoplankton sampled from both sampling stations3. RESULTS AND DISCUSSION 


\subsection{CONCLUSION}

In conclusion, the conventional morphological identification of Icthyoplankton stages is highly challenging and hence additional molecular technique would be instrumental in identifying cryptic species to their corresponding taxon. Modified bubu light trap method employed in this study can be successfully used in sampling Icthyoplankton from sampling zones where depth and turbidity are the limiting factors. Further investigation on the larval distribution in Kuantan River is crucial for various fishery management practices and to observe the post-monsoonal succession.

\subsection{ACKNOWLEDGEMENT}

This project was funded by special Fundamental Research Grant Scheme (FRGS 15-176-0417) under Flood disaster management project, MOSTI, Malaysia.

\subsection{REFERENCES}

[1] A. Sabatés, M. P. Olivar, J. Salat, I. Palomera, F. Alemany, Physical and biological processes controlling the distribution of fish larvae in the NW Mediterranean, Progress in Oceanography. 74 (2007), 355-376.

[2] R. Lopes, M. Katsuragawa, J. F. Dias, M. A. Montú, J. H. Muelbert, Zooplankton and ichthyoplankton distribution on the southern Brazilian shelf: an overview. Scientia Marina. 70 (2006), 189-202.

[3] B. A. Muhling, L. E. Beckley, J. A. Koslow, A. F. Pearce, Larval fish assemblages and water masses structure off the oligotrophic south-western Australian coast. Fish Oceanography. 17 (2008), 16-31.

[4] M. S. Islam, M. Hibino, M. Tanaka, Distribution and diets of larval and juvenile fishes: influence of salinity gradient and turbidity maximum in a temperate Estuary in upper Ariake Bay, Japan. Estuarine, Coastal and Shelf Science. 68 (2006), 62-74

[5] A. K. Whitfield, Ichthyofaunal assemblages in estuaries: a South African case study. Reviews in Fish Biology and Fisheries 9 (1999), 151-186 [6] F. J. Neira, I. C. Potter, J. S. Bradley, Seasonal and spatial changes in the larval fish fauna within a large temperate Australian Estuary. Marine Biology. 112 (1992), 1-6

[7] A. Faria, P. Morais, M. A. Chıcharo, Ichthyoplankton dynamics in the Guadiana Estuary, South-East Portugal. Estuarine, Coastal and Shelf Science 70. (2006), 85-97

[8] U. M. Azeiteiro, L. Bacelar-Nicolau, P. Resende, F. Goncalves, M. J. Pereira, Larval fish distribution in shallow coastal waters off North Western
Iberia (NE Atlantic) Estuarine, Coastal and Shelf Science. 69 (2006), 554566

[9] K. C. A. Jalal, B. Y. Kamaruzzaman, A. Arshad, R. Ara, Diversity and Distribution of Fishes in Tropical Estuary Kuantan, Pahang, Malaysia, Pakistan Journal of Biological Sciences. 15 (12) (2012), 576-582.

[10] K. Kawaguchi, Guide for sampling and identification of fish larvae in the straits of Malacca, Muchtar Ahmad and Hamdan Alawi (Eds.), Penrerbit Unri Press., 2003, pp 66. ISBN 9793297689

[11] E. H. Ahlstrom, G. Moser, Characters useful in identification of pelagic marine fish eggs, CalCOFI Reports. XXI, (1980), 121-131.

[12] M. P. Fahay, Guide to the early stages of marine fishes occurring in the western North Atlantic Ocean, Cape Hatteras to the southern Scotian Shelf, J Northwest Atlantic Fishery Science. 4 (1983), 1-423.

[13] H. G. Moser, The early stages of fishes in the California Current region, CalCOFI Atlas. 33(1996), 1-1504.

[14] M. P. Olivar, L. E. Beckley, Early development of Diaphus spp. (Pisces: Myctophidae) of the Agulhas Current, South African journal of marine science. 16 (1995), 129-139.

[15] M. P. Olivar, H. G. Moser, L. E. Beckley, Lanternfish larvae from the Agulhas current (SW Indian Ocean), Sci Mar. 63 (1999), 101-120 DOI: 10.3989/scimar.1999.63n2101

[16] W. J. Richards, Early stages of Atlantic fishes. An identification guide for the Western Central North Atlantic, CRC Press., Florida. 2005, p. 2672.

[17] J. S. Nelson, Fishes of the world, fourth ed., John Wiley \& Sons, New Jersey. 2006, p. 601.

[18] L. Chicharo, A. Faria, P. Morais, A. Amaral, C. Mendes, M. A. Chicharo, How to sample fish larval fish for taxonomical and ecophysicological studies in shallower temperate coastal ecosystems?, Cahiers de biologie Marine. 50 (2009), 311-318.

[19] N. Hubert, B. Espiau, C. Meyer, S. Planes, Identifying the ichthyoplankton of a coral reef using DNA barcodes. Molecuar ecology resources. 15(1) (2015), 57-67.

[20] S. Ajmal Khan, P. S. Lyla, B. Akbar John, C. Prasanna Kumar, S. Murugan, K.C.A. Jalal, DNA barcoding of Stolephorus indicus, Stolephorus commersonnii and Terapon jarbua of parangipettai coastal waters, Biotechnology. 9(3) (2010), 373-377.

[21] D. Mazurais, M. Darias, J. L. Zambonino-Infante, C. L. Cahu, Transcriptomics for understanding marine fish larval development, Revue Canadienne de Zoologie. 89(7) (2011), 599-611. 